PLANTS PEOPLE

POSSIBILITIES

\title{
Gutta Percha Trees of the Malay Peninsula
}

\section{Author(s): J. S. Gamble}

Source: Bulletin of Miscellaneous Information (Royal Botanic Gardens, Kew), Vol. 1907, No. 4 (1907), pp. 109-121

Published by: Springer on behalf of Royal Botanic Gardens, Kew

Stable URL: http://www.jstor.org/stable/4111825

Accessed: 27-06-2016 04:11 UTC

Your use of the JSTOR archive indicates your acceptance of the Terms \& Conditions of Use, available at

http://about.jstor.org/terms

JSTOR is a not-for-profit service that helps scholars, researchers, and students discover, use, and build upon a wide range of content in a trusted digital archive. We use information technology and tools to increase productivity and facilitate new forms of scholarship. For more information about JSTOR, please contact support@jstor.org.

Royal Botanic Gardens, Kew, Springer are collaborating with JSTOR to digitize, preserve and extend access to Bulletin of Miscellaneous Information (Royal Botanic Gardens, Kew) 
ROYAL BOTANIC GARDENS, KEW.

B U L L E T I N

OF

MISCELLANEOUS INFORMATION.

No. 4.]

$[190 \%$.

\section{XXIII.-GUTTA PERCHA TREES OF THE MALAY PENINSULA.}

\section{J. S. GAMBLE.}

The recent publication by the Asiatic Society of Bengal of Part 17 of the "Materials for a Flora of the Malay Peninsula," by Sir George King and the writer, makes it possible to attempt to identify the chief trees, mostly belonging to the natural order Sapotaceae, which yield the very vaiuable "gutta percha." It appears that, so far as is at present known, the Sapotaceae of the Malay Peninsula belong to eight genera and include 50 species, mostly large trees, valuable not only for gutta percha but as yielding strong and durable timbers, mostly of a reddish colour, hard, and suitable for building purposes and engineering work. The species are here enumerated, with such information about them as has been obtained :-

1. Chrysophyluum, one species, C. Roxburghii, G. Don. The Star-apple; a moderate-sized tree with edible fruit and useful wood.

2. Sarcosperma, one species, S. paniculatum, Stapf \& King. A moderate-sized tree chietly found among large bamboos, on river banks, or in mixed forest; not known to be a producer of gutta percha.

3. SideroxylON, five species, with a sixth (S. Wallichianum, G. Don) of doubtful identification. The most important species is S. malaccense, Clarke, which, according to Mr. Cantley, gives the valuable 'Daru' or 'Dedâru' wood. This statement is, how. ever, objected to by Mr. H. N. Ridley, who says, in the Agricultural Bulletin of the Straits and Federated Malay States for March, 1906, that the 'Daru' trees he had been shown in Sumatra certainly did not belong to this species. He thinks that probably 'Daru' wood is yielded by more than one species, most of it coming from Sumatra. The question ought to be gone into

1375 Wt $4 / 07$ D \& $\$ 2927805$ 
and definitely settled, and it may be hoped that Mr. Ridley may find time to do it. Of the other species, the most common is evidently S. ferrugineum, Hook. \& Arn., a small tree which extends also to Burma, the Andaman and Nicobar Islands, the Archipelago, and even to the Philippines and China. S. firmum, Pierre, has only been once collected in the Peninsula, but extends to Bangka and the Philippines. The other two species are Peninsular only, S. Maingayi, Clarke, and S'. Derryanum, King \& Gamble, the last-named found so far only in Perak. None of the species of this genus are recorded as yielding gutta percha.

4. Ison ANDRA, two species, both small trees from Perak, and both apparently rare and new to science, I. perakensis, King \& Gamble, from elevations of 1,000 to $1, \overline{5} 00 \mathrm{ft}$., and I. rufa, King \& Gamble, from rather lower down.

5. Paykna, nine species, some of which are important as giving gutta percha of minor quality. P. Maingayi, Clarke, is a large tree with leaves which resemble those of Palaquium Gutta in having the lower surface covered with golden-brown pubescence. On this Ridley says: "A quite worthless but beautiful tree which is very often mistaken at first sight for gutta percha. Its conspicuous golden leaves, usually much longer than those of Palaquium Gutta, at first glance suggest those of that plant. Its gutta, too, when fresh drawn and set, has the same red speckled appearance as first-class gutta, but never hardens, remaining a putty-like mass which usually at least becomes quite black after a short time. It is very common in Malacca and open country generally in the Peninsula. It is known as 'Malaim Pata,' and is said to give a good durable timber, heavy, and dark brown, used in housebuilding. It attains the height of about 70 feet. It is one of the numerous plants known as 'Niato,' a name applied to a large number of gutta-producing plants, and, according to $\mathrm{Mr}$. Curtis (late Superintendent of the Penang Botanic Gardens), the Malays call it 'Taban Yercha,' the real gutta percha being always known as 'Getah Taban,' and not as '-percha.' The seeda are imported from Sumatra for oil." An allied species, but with glabrous leaves, so far known only from Perak and Borneo, is P. longipedicellata, Brace. Both these have rather large flowers.

There are four species with small or medium-sized flowers. Of these the most important is $P$. Leerii, Benth. \& Hook. f., which, according to Ridley, is the white gutta percha, 'Getah sundek,' occurring all over the Peninsula as well as in Sumatra, Bangka, Borneo, and Amboina. He says that at one time a good deal of the 'Getah Sundek' was collected in the Dindings, the produce of $P$. Leerii. A full account of the information then available regarding this kind of gutta percha is given in the "Report on the progress and condition of the Royal Gardens at Kew for 1881," p. 40. The first specimens which admitted of identification were sent by M. Bran de St. Pol Lias and Mr. (afterwards Sir Hugh) Low, British Resident in Perak, to Dr. Beauvisage, who identified them with Kerataphorus Leerii, Hassk., which species was merged in Payena in the "Genera Plantarum." Specimens sent at the same time to Dr. H. Trimen, Director of the Royal Botanic Garden, Peradeniya, were identified by him (Report for 1880) as belonging 
to Payena. Previous to this, in 1878, Dr. Dennys, Assistant Curator of the Raffles Museum, Singapore, had reported that 'Gutta Sundek' was a somewhat inferior variety of gutta percha to that yielded by 'Gutta Taban' (Palaquium Gutta). The information of 1881 was supplemented in 1884 by the following extract from notes by Mr. Wray, published in the "Tropical Agriculturist" for October, 1884, p. 289 :-

"This species grows in swampy places near the coast, and I found one tree with its root in a small creek, the water of which was quite salt, and only a short distance from the regular mangrove trees fringing the stream. The leaves are small, shiny, and have a reddish tint when young. The bark is about three-eighths of an inch thick and dark brown in colour, moderately rough.

"The flowers are white, and the fruit is sweet and eaten by the Malays. Its gutta is like 'Taban Sutra' in appearance, and is collected by scoring the bark, catching the sap and boiling it until it coagulates. A tree measuring 2 feet and 8 inches in circumference at 3 feet from the ground, and $38 \frac{1}{2}$ feet to the first branch, that I had felled gave $6 \frac{1}{2} \mathrm{oz}$. of gutta."

In the Malay Archipelago Payena Leerii appears to be a much more important source of gutta percha than had been suspected. From the important "Observations on Gutta Percha" by Dr. Burck, translated in the "Tropical Agriculturist," it appears to be not uncommon in Southern Sumatra.

In the Palembang district it is known as 'Balam Tandock,' 'Balam Tjabe,' 'Balam Sonte,' 'Balam Troeng.' According to Dr. Burck, M. Van Leer, Health Officer of the 1st Class, from whom Messrs. Teysmann and Binnendyk obtained their specimens, remarks that the 'Pohon Balam' is a tree frequent on high lands, attaining to a great age and exceptionally large girth. Bees form nests on it, and on this account the tree is planted and cultivated more for its wax than for gutta percha. The ratives only fell them for the gutta percha when they think them too old to be useful for wax production. The method of collecting the gutta consists "in cutting the tree down, cutting off the crown and making a number of incisions in the trunk and principal branches."

In the district of Soepajang the gutta is called 'Balam Pipis.' Dr. Burck states that the tree grows above elevations of $2,000 \mathrm{ft}$. in humus soil in thick woods and needs shadow and moist ground. The fruits are pear-shaped, green and hard.

In Bangka the tree, according to Dr. Burck, is known as the ' Koelan.' "The tree produces a large amount of gutta, the fruit is eaten, and the gutta is used for making the handles of billhooks and for buckets, whilst the wood serves for household furniture and oars of prahus."

In West Borneo Dr. Burck identifies with this species the guttaproducing tree known as 'Niato.'

M. de Beauvisage, in his "Contribution à l'étude des origines botaniques de la Gutta Percha," Paris, 1881, mentions that the tree is called 'Balam Soentei' in the Rhio Archipelago. 
Allied to $P$. Leerii is a species, perhaps more common in the Peninsula, extending northwards to Kedah and across to Borneo, P. Havilandi, King \& Gamblo. According to Ridley, it is known as 'S'marum,' and has a gutta percha as good as that of P. Leerii.

The most common species of Payena in the Malay Peninsula is, however, P. lucida, A. DC., of which Ridley says : "A common tree of no great size known as ' Niato,' 'Niato Putih,' 'Niato Balam,' 'Tanjong Hutan' (from a resemblance to Mimusops Elengi), but giving no gutta. The timber is poor and not large." Near it, distinguished by ferruginous-pubescent instead of glabrous leaves, is $P$. dasyphylla, Pierre, a large tree, reaching 80 to 100 feet in height and a considerable girth. It has been found on the hills of Larút in Perak and extends to Sumatra and Java, and, according to de Vriese, gives a gutta percha only used for adulteration, though Motley seems to consider this unlikely as so little is produced that it would not be worth using.

There are three other species of Payena, so far only imperfectly known and hitherto undescribed: P. sessilis, King \& Gamble, collected by Ridley in Singapore ; P. obtusifolia, King \& Gamble, collected by Father Scortechini in Perak; and $P$. selangorica, King \& Gamble, collected by Ridley in the Bukit Kutu woods of Selangor. None of these have, so far, been reported as giving gutta percha.

6. BAssia contains, so far as at present known, 17 species, of which no less than 13 have now been described for the first time. $B$. aristulata, King \& Gamble, is a tree found by Father Scortechini in Perak and said by him to give a gutta percha. B. malaccensis, King \& Gamble (Payena malaccensis, Clarke), is a tree of Perak, Malacca, and Singapore, apparently quite common and reported by Wray to give a sticky gutta in small quantities. B. Curtisii, King \& Gamble, a tree of Penang and Perak, is the 'Getah Ganau' of which Wray reports : "It grows on the hills up to an elevation of 2,600 feet. The bark is light gres and the wood seems to be of good quality. The gutta is white and hard and is used only for mixing with better kinds." B. Motleyana, Clarke, is an erect lofty tree of swampy places, first described as Isonandra Motleyana by de Vriese from specimens collected in Borneo, where it is called 'Kotian.' He says that it produces plenty of gutta, but of bad quality, resinous, and brittle. He says also that the seeds give a clear, yellow viscous oil with the taste of bitter almonds, and that this oil is used in sweetmeats and is much esteemed in Bandjermassin. The remainder of the Malay Peninsula species of Bassia are not reported to give gutta percha. The species are : B. Kingiana, Brace, a good-sized tree of Perak and Singapore; B. Kunstleri, Brace, a tree of the hills of Perak; B. penicillata, King \& Gamble, a large tree of Province Wellesley, said by Mr. Curtis to be common and to be called 'Minjoto'; B. laurifolia, King \& Gamble, a good-sized tree of Perak, one variety of which extends to Kedah ; B. rupicola, King \& Gamble, B. perakensis, King \& Gamble, and B. cuprea, King \& Gamble, trees of Perak ; B. argentea, Clarke, a large tree of Malacca ; B. Braceana, King \& Gamble, a spreading tree apparently very common in Penang and Perak, and B. longistyla, King \& Gamble, of Perak and Singapore, a tree closely allied to it ; B. cuneata, Blume, a tree of 
Malacca and Singapore; B. penangiana, King \& Gamble, and B. erythrophylla, King \& Gamble, trees of Penang only collected by Mr. Curtis and apparently scarce.

7. Palaquium, 12 species, among which is the most important of the gutta percha yielders, $P$. Gutta, Burck. It is a large evergreen tree with obovate coriaceous leaves densely covered beneath with golden pubescence. It was first described by Sir W. Hooker in 1847 as Isonandra Gutta. In the Kew Gardens Report for 1881 is given a long extract from the report of Dr. Dennys, Curator of the Raffles Museum in Singapore, in 1878, who said that the trees are chiefly found on the slopes of low hills in dense forest, and that in order to procure the juice the "tree is felled and the bark ringed in spaces a foot wide and about 15 to 18 inches apart. The upper end of the tree is usually cut off, as this is said to cause it to bleed more freely. Buckets made of wood, cocoa-nut shells or leaves stitched together are used to collect the juice, which is then poured into a hollow bamboo." The juice is then heated until it solidifies and can be moulded into a convenient shape for transport.

The tree is known as 'Gutta Taban' or 'Taban Merah," 'merah' meaning red. Dr. Dennys says that the term is applied on acconnt of the colour of the flower, but there seems some reason to think that it is from the colour of the gutta percha. Various other names are given by different writers and collectors, but it seems so doubtful that they have properly identified the tree that it is well to leave them for further local investigation.

The following extract is from Mr. Wray's notes and describes his experience of the tree in Perak :-

"This tree, from which the best kind of Gutta Percha is obtained, grows, or rather used to grow, throughout the jungles of the plains of Perak and a short way up the sides of the hills.

"It seems to like a considerable amount of moisture, and will even grow with its roots in a running stream. It is a tree of large size, attaining a diameter of 4 to 5 feet, and a height of between 100 and 200 feet.

"It has large thin buttresses around its base, which often present, on their upper portions, a convex profile, and, on a large tree, attain a height of 6 to 8 feet, and a span at the base of 4 to 5 feet from the trunk. As far as I have yet seen, they never form an arch, but have their lower parts buried in the earth, from the trunk to their extremities.

"When growing in the forest the tree has a clean, straight appearance, the former being due apparently to the bark peeling off in irregular pieces. The bark is of a rich brown-red colour, and from one third to half-an-inch in thickness.

"Inside the epidermis it is of an Indian-red tint; and when cut, the milk white sap comes out, at first in small beads, which, enlarging, soon join and cover the injured part with a coating of a cream-like consistency. The leaves are lanceolate on a young tree, and roundish oval, with abruptly acuminate points on a tree of mature growth. The margin is entire, and they are covered on their undersurface with minute silky warm-brown hairs. The 
leaf stalks and young wood are also covered in a similar manner, which gives the whole tree, when looked at from below, a brownish tint, by which it may generally be recognised. The upper surface of the leaf is dark green, and the veins are not prominent. The calyx consists of six sepals, three of which are superior to the others and alternate with them. They are coated, like the backs of the leaves, with silky brown hairs. The corolla is white, and is divided into six petals. The style, which is simple, is sometimes persistent, and may be seen on the ripe fruit. There are six ovules, but one or two seeds only arrive at maturity.

"On the apex of the young fruit the six carpels of which it is formed can be distinctly traced. The fruit is coated like the backs of the leaves, with brown down ; its flesh is soft, and it is sweet, but it has a disagreeable flavour of gutta percha.

"The seeds are very oily, and they are, together with some of the seeds of nearly allied species, collected by the Malays and the Sekais, who dry them in the sun for some days, and then express the oil by putting them between two flat pieces of wood, and applying pressure by clamps and wedges.

"The oil, which is solid at the ordinary temperature (that is up to $90^{\circ}$ ), is highly esteemed for cooking purposes. Birds, squirrels, monkeys, \&c., are very fond of the fruit and of the seeds, which adds to the difficulty of obtaining them.

"It flowers in the month of March and ripens its fruit in June, but the Malays assert that it only fruits once in three or four years.

"The gutta of this variety is red, and the colour is not due to an admixture of bark as is frequently stated. It is probable that other varieties of gutta may be sometimes mixed with bark to make them look like 'Taban Merah' and so command a higher price than they otherwise would; but the true 'Getah Taban Merah,' is red per se, and the water in which it is cleaned, although changed many times, still becomes deeply dyed with that colour. Specimens of this, in fruit, together with wood, bark and gutta, I sent to the Royal Gardens at Kew, Calcutta and Ceylon, on May 30th, 1863."

There is a form of Palaquium Gutta known as var. oblongifolium which was considered by Dr. Burck to be a distinct species, but which the authors of the "Malay Materials" as well as Mr. Ridley and others agree in making a variety only. It is a very large tree, reaching 80 feet in height and two feet in diameter, and it has larger leaves and rather larger flowers than the type, like which it is an important yielder of gutta percha. Wray gives its name as "Getah Taban Sutra," and says that it prefers the banks of streams at an elevation of about 500 to 600 feet. He says that the gutta percha is of a pale reddish brown and is collected in the same way as that of "Taban Merah."

Allied to Palaquium Gutta and having the leaves beneath covered with a similar golden pubescence is $P$. Oxleyanum, Pierre (Dichopsis pustulata, Hemsl.), a common species found in all the provinces of the Peninsula. It is known to Malays as "Taban Sutra" or "Taban Putih" or (according to Wray) "Taban Chaia," aud gives a gutta percha of rather inferior quality. Mr. Derry 
reports that it is "good but does not yield so freely as, and is not so highly priced as the produce of "Taban Merah." The following extract from Wray's notes as "Taban Putih" seem to refer to this species :-

"This tree cannot be told, by its outward appearance, from Palaquium Gutta, except that its leaves are rather larger. It has large buttresses, with convex tops, and the bark is nearly of the same shade, but rather browner. The fruit alsc seems to be similar, and the flowers are white; so that it is not until the tree is felled, that any very distinctive character appears. It is then found that the sap, which is much more copious, does not coagulate quickly, and when it does, it is of a dirty white colour, and has a much higher softening point than any of the higher kinds, even boiling water not being sufficiently hot to thoroughly soften it. This tree grows on the hills up to an elevation of 2,500 feet above sea-level.

"I have never seen it growing on the plains, nor in fact lower down than 1,800 feet. It ripens its fruit in the month of February.

"The gutta is collected by felling the tree, ringing the bark, and placing leaves, bamboos, \&c., under it to catch the sap ; which is afterwards boiled, and the natives often add salt to hasten its coagulation.

"It is frequently adulterated with the gutta from 'Kayu Gelutong' (Dyera costulata, Hook. f.), and from two or three of the species of Bassia.

"The usual method of mixing them is to do so before the sap has coagulated, as afterwards, owing to the high melting point of 'Taban Putih,' they cannot be so easily and intimately combined. A tree of ten inches of diameter at four to five feet from the ground, gave 2 lbs. 11 ozs. of fairly clean gutta percha.

"There is a variety which differs from the above in having smaller leaves, and in the shape of the fruit, which is longer in proportion to its breadth. I have found it growing on the hills at 2,300 feet elevation, and it ripens its fruit in the month of February."

The variety referred to is that mentioned in the "Malay Materials" as P. Oxleyanum var. glabrata, King and Gamble.

$P$. obovatum, (Griff.) King and Gamble, is a large tree, common throughout the Peninsula and extending northwards to Tenasserim and westwards to Sumatra. It gives, according to Curtis, "only a low class bastard gutta percha of little value ;" but Mr. Kurz reported it as yielding a fair sort of gutta percha, and Kidley also gives it a better character saying that it yields "a fairly good second class white gutta." He gives it the name "Taban Putih," which is also one of the names given to $P$. Oxleyanum, and says, after Curtis, that it is also called "Niato Bunga," "Niato Tembaga," and "Niato Balam," both the words " Niato" and "Balam" being Sumatran equivalent for the Peninsular "Taban." Ridley considers the Dichopsis Krantziana, Pierre, to be closely allied to this species. It is a tree of the forests of Cambodia and Cochin China, and its gutta is said by Mr. Ridley to be exported from French Indo-China in the form of twists, but to be only of low value. 
P. Maingayi, (Clarke) King and Gamble, is a tree somewhat like $P$. obovata, but has the leaves golden-pubescent instead of grey beneath. It is found in Perak and Malacca, and according to Wray is called "Getah Taban Simpor" also "Gelntong Batu" but has no connection with the real "Gelutong" (Dyera costulata, the produce of which is an india-rubber rather than a gutta percha). The following is Wray's account of this species and its gutta percha.

" This tree may be readily distinguished from the foregoing by its large dark green leaves, and by its prominent veins at the back, which are covered by coarse, silky light-brown hairs, the back of the leaf itself being only sparingly covered by them. The bark is about half-an-inch thick, rough, and of a reddish-brown colour, much covered by a greyish lichen. It has medium-sized buttresses, with a concave outline. One tree that I measured was 3 feet 3 inches in diameter, at 6 feet from the ground, and from that height the buttresses sloped out until they reached the ground, having a spread of about 3 feet from the trunk.

"The flower is white, and comes out in the beginning of April or the end of March, but its fruit I have not yet seen.

"I had one tree felled, which, at 3 feet from the ground measured 17 inches in diameter and 63 to the first branch, The weight of gutta obtained was $12 \mathrm{oz}$. The sap, by the aid of heat, and stirring, coagulated in twenty-three hours after tapping.

"This gutta is sold under the name of 'Getah Putih.' The tree grows on hills up to about the same height as "Taban Putih.'"

P. Clarkeanum, King \& Gamble, is closely allied to P. Maingayi, but differ in having much more hairy leaves. It is found in the hills of Perak, and (according to Ridley) Selangor. Wray says of it: "it has not enough gutta in it for it to be worth extraction," and Ridley says : "Mr. Arden, who sent specimens from Selangor, says that the Malays call it 'Getah Ketapang' (doubtless from its resemblance to the 'Ketapang' tree [Terminalia Catappa]), and find its latex useful for adulterating gutta percha."

P. xanthochymum, Pierre, the Dichopsis rubens of the Flora of British India, is a large handsome tree of Perak, Malacca and Singapore, extending to Borneo, the leaves of which turn bright red when they dry. According to de Vriese it produces a gutta percha of a yellowish colour and second quality, but Ridley says he has never heard of its being utilized in the Peninsula.

$P$. bancanum, Burck, is a gigantic tree reaching, according to Curtis, 100 feet in height, according to Kunstler 120 feet. It seems to be common in the Peninsula and to be found, across the Straits, in Bangka. Curtis has reported that it gives a kind of gutta percha, and on this Ridley remarks that "it certainly does contain a small quantity, but it appears to be very scanty." $\mathrm{He}$ says there is a splendid specimen of it in the Singapore Botanic Gardens.

The remaining five species are mostly scarce and of little importance for gutta percha. P. Ridleyi, King \& Gamble, which Ridley says is known as "Niato Hitam" or "Maiang," is a large 
tree of Singapore with a heavy timber used in house-building, flexible and durable, but difficult to saw.

P. microphyllum, King \& Gamble, is a small-leaved species of Singapore, and $P$. hexandrum, (Griff.) King \& Gamble, a tree of Malacca and Singapore, described in the Flora of British India as Dichopsis hexandra, and said to extend to Burma. P. Herveyi, King \& Gamble, is a large tree known as "Jongek " or "Jungak." It is found in Perak and Malacca, and Wray says it gives a sticky worthless gutta. Ridley says that it has an inferior light wood and that it does not seem to be common. P. stellatum, King \& Gamble, is a Bassia-like species onl 5 once collected, viz., in Perak by Scortechini, who reported it to yield good gutta but in small quantities.

8. Mimusops. In this genus come the two well-known and important trees $M$. Elengi, L., and $M$. Kauki, L., neither of which is, however, known to yield gutta percha.

The result of this enumeration of the Sapotaceous trees of the Malay Peninsula seems to be that the only really important gutta percha tree is Palaquium Gutta, the "Taban Merah," with its variety oblongifolium, "Taban Sutra"; that three other species afford a second class product, viz. : P. Oxleyarum, usually called "Taban Putih" or "Taban Chaia," P. obovatum, also called "Taban Putih," and Payena Leerii "Sundek"; that a few others give sunall quantities of poor quality and little value, and that the rest yield none at all. It would seem, therefore, advisable that so far as possible artificial cultivation should be restricted to the four species mentioned, and this is practically what is being done. A brief account of what is being done in the forests of the Peninsula to increase the out-turn of gutta percha, and to utilize in the best way possible the produce of the natural forests, may here be of interest.

In 1900 , Mr. H. C. Hill, who had been acting as InspectorGeneral of Forests in India but was then on furlough, was asked by the Colonial Office to visit the Straits Settlements and the Federated States and advise on forest questions. His concise but very interesting and valuable Reports were printed by the Straits Government. His recommendations, as regards the Straits Settlements, were :-

“(1) The reservation of all areas where the trees (there are several species of Palaquium yielding good gutta percha) are found growing naturally, or can be planted with good prospect of success.

"(2) The discontinuance of the experimental planting of all sorts of indigenous and exotic trees, and the concentration of efforts on the formation of one or two large plantations of the most valuable indigenous tree, the Gutta Percha." He further recommends the appointment of an experienced Indian Forest Officer, preferably from Burma, to supervise forest work.

As regards the Federated States his proposals were :-

(1) To declare all "Taban" (Palaquium) trees to be "reserved," and to prohibit their being felled. 
(2) The reservation of the gatta percha-providing forests and their working by means of a simple working plan. The following extracts give the details of his proposals.

"The systematic working of these forests should be arranged for by means of a plan by which the same area would come under operation after an interval of not less than five years and not more than 10 years. The forest should be divided into a number of blocks (from 5 to 10), and these should be gone over annually one by one. The operation would consist in giving more space and light to each Palaquium species tree, and in uncovering the crowns of the trees by either felling or girdling all trees overtopping them, interfering with their side development or tending to suppress them. At the same time, care must be taken not to too suddenly isolate trees that have till then been growing under dense shelter.

"All trees over a certain size, say, 1 foot 6 inches in girth, should be enumerated, when found, and be marked with a ring of white paint, and all suppressed seedlings and saplings, which are not required to form the crop in that particular place, should be dug up for transplantation elsewhere.

"The extraction of the gutta percha, both from the trees and the leaves and twigs, is an important matter.

"It has been the custom of the hill tribes to cut down the tree, and that has led to the disappearance of most if not all of the mature trees. It is rare to find a tree over 1 foot 6 inches in girth. From small incisions made in the bark, I see no reason why trees should not yield up their gutta percha, just as other trees yield their rubber; but should this process fail, it will be necessary to cut down the trees at a suitable age for the production of coppice shoots. In the meantime, experiments should be made in extracting the gutta at different seasons from the living trees, so that by the time the selected and tended areas are fit to yield gutta percha it will be known whether they have to be coppiced or not.

"Processes have been patented for extracting gutta percha from the leaves and twigs, but it is donbtful whether they can be worked profitably at any distance from the forest producing the leaves. The eventual method of treating these forests must remain for future determination.

"The working plan should also prescribe the planting up of all blank areas, in which no Palaquium species are growing naturally, the forest being gone over block by block as plants are available and the forest rendered complete. Blanks of less than a square chain $\left(66^{\prime} \times 66^{\prime}\right)$ need not be considered. This work, owing to the uncertainty of procuring plants, can only follow the improvement fellings and must be independent of them.

"The making of suitable paths and lines of export, in so far as the block divisional lines are insufficient, should also be prescribed in the working plans."

It is interesting to note that he estimates the gutta percha of Palaquium Gutta as worth $\$ 500$ a pikul (1331 $\frac{1}{3}$ lbs.), i.e., $3 \frac{3}{4}$ dollars a pound, while that of $P$. Oxleyanum and Payena Leerii is only worth $\$ 150$ a pikul, i.e., $1 \frac{1}{8}$ dollars a pound. 
The officer appointed as Conservator of Forests was Mr. A. M. Burn-Murdoch, and his important paper in Vol. xxxi., p. 309 of the "Indian Forester" 1905, "Some facts about gutta percha" gives a full and valuable account of what has been done to follow out Mr. Hill's recommendations. It is impossible to do better than to quote the following extracts from Mr. BurnMurdoch's paper.

"Palaquium Gutta is found in all four States, the best areas lying between two degrees and five degrees north. It must be considered as a dominant species, but exists at present, owing to the unregulated and wholesale fellings by natives some years ago, only in the seedling and small pole stage.

"It occurs most frequently on the low hills and plains, often on steep hill sides, and up to 2,000 feet above sea-level, and even 3,000 . It is found well represented in large blocks of forest, varying in size from a few hundred acres to 10,000 or 15,000 acres in extent, while it may be practically absent in other areas for long distances. On close examination a great many of the young plants are found to be stool shoots, but there are many seedlings also, although seed trees are not now to be found. This looks as if the felling of mature trees did not cease until comparatively recently. The 'Taban' tree is a shade bearer of the most pronounced description, and is able to maintain the struggle for existence successfully, if slowly, in these dense evergreen forests. It grows to a considerable size; the largest I have actual knowledge of in this country was in Penang, and measured when blown down 5\% feet in height and 42 inches in circumference at 14 feet from the ground. I have seen mention of a tree 140 feet high in the Philippines, and there is no doubt that it is an exceedingly slow grower. At present poles 30 to 40 feet high are fairly common in these States, but large trees are rarities."

"The qualities of gutta percha became known about 1845 , and the demand steadily increased from that time, till in the seventies there was a rush for it by the natives of these States, the price rising rapidly till 1902. Between 1895 and 1900 the exports from Singapore rose from 2,642 tons to 5,831 tons. It may safely be said that from 1890 onwards the natives of these States were doing their best to obtain gutta percha. Their method of extraction consisted in felling every tree they came across and extracting the latex in a wasteful, rough and ready manner, so that by the time the authorities awoke to the fact that Palaquium was being exterminated (about 1898), it was too late to save trees large enough to produce gutta percha. It is difficult to see how this could have been prevented, however, as at the time there was no properly organised Forest Department, and whatever measures might have been adopted it would have been impossible to effectively carry out in these dense, unpopulated, evergreen forests.

"In Perak the export of gutta percha was prohibited in 1881, but allowed again in 1887, the issue of passes to collect being prohibited in 1900. The first timber rules, published in 1898 by the British Residents of the various States, contained the initial protective measures, which were to the effect that no rubberbearing tree should be felled if of less than eight inches diameter. 
This rule could not, I imagine, be enforced in practice, owing to the want of an organised staff. In 1899 and 1900 the matter was taken up by the High Commissioner and the Resident-General, and in the latter year the British Resident, Pahang, issued orders to all his officers to do all that lay in their power to prevent the destruction of gutta percha producing trees.

"The question of planting was also discussed, but not in a very practical manner.

"The Forest Department was started in each State by the appointment of a local man, in Perak in 1895, in Selangor in 1898, in Negri Sembilan, in 1899, and in Pahang not till 1902, when a member of the Indian Provincial Forest Service was sent over on deputation at my request, I having been deputed from India in October 1901, as Conservator of Forests.

"Early in 1902 I suggested that an export duty of 80 per cent. ad valorem be imposed on all gutta percha leaving these States, as a means of putting a stop to the extraction and collection of this product, a considerable period of absolute rest being obviously indicated for all gutta percha producing trees.

“The rules were also amended and the felling of trees for the extraction of the latex was prohibited. In addition to these precautions departmental instructions were issued to the effect that no licences for the extraction of gutta percha were to be issued. At the present time therefore it must be difficult to collect gutta percha and export it in sufficient quantities to make it pay. That a certain amount of smuggling goes on I have no doubt, from the fact that two or three cases have come to light in which Chinamen were found in possession of small quantities and were convicted of the offence. Since 1902 the staff of the Forest Department has been greatly increased, and I have reason to believe that the Government have done and are now doing all that is in their power to assist in the preservation of this valuable product.

"As regards measures for protection from other causes of destruction, such as alienation of land for mining and agriculture, the only plan is to reserve all the valuable Palaquium areas, constituting them forest reserves wherever possible, without interfering with valuable tin-bearing land. We already have an area of about 60,000 acres reserved, fairly rich in young Palaquium, chiefly in Perak and Selangor, and probably as much more remains to be taken up in Pahang and elsewhere.

"Again, before any large area of land is alienated the department is referred to, and if alienation takes place in spite of the presence of Palaquium, we are given the opportunity of taking away the young plants and transplanting them into reserved areas, In the course of time, when all forest reservation has reached its natural limit, Palaquium is bound to disappear from all tracts outside, nor does this matter, as it is only practically possible to watch defined areas when placed completely under the control of the Forest Department.

“The systematic exploitation of the gutta percha areas will only be possible in reserved forests, tracts being taken in hand annually. 
"The natural regeneration of Palaquium, as already stated, is very good, but growth is slow and assistance must be given. Our object now is to encourage only the best species, $P$. oblongifolium and P. Gutta. Regular plantations, i.e., planting in cleared areas from seed, is at present impossible in these States, as no seed is available. The method followed by the Forest Department here is to cut lines through the dense undergrowth in the forest reserves, taking up regular areas in turn, and to transplant into these lines young Palaquium seedlings taken from outside the reserve in forests that cannot for various causes be protected, or taken from groups inside the reserve where they are growing too close together. At the present time we have an area of more than 1,000 acres so planted in Selangor.

"In the Trollah reserve in Perak Palaquium seedlings are so numerous in the seedling and pole stage that planting over a considerable area is unnecessary. Here we resort only to improvement fellings, transplanting young plants into blanks only wherever necessary. The improvement fellings consist in clearing away undergrowth interfering with young Palaquium plants, the operation being repeated yearly or once in several years, as may be necessary. By this means the rate of growth of the young tree is greatly increased. I have found the effect of this process to be very beneficial even in the two years since it was started. By such simple methods as these it is hoped in a few years to have a very considerable area of young Palaquium trees about 40 to the acre. One advantage in this system is the freedom from the attacks of insects to which trees grown in pure plantations are liable. A similar area to that in Selangor exists in Malacca, but the plants are put in closer together and were obtained from Sumatra. Similar plantations exist at Bukit timah in Singapore, and at Batu ferringi in Penang, but on a small scale."

Thus it will be seen that the Government of the Straits Settlements and Federated Malay States has taken strong measures to prevent the destruction of the gutta percha forests and to provide for a permanent supply when the reserves and plantations after some years can begin once more to produce a regular yield.

\section{XXIV.-FUNGI EXOTICI : VI.}

\section{G MASSEE.}

Of the ten new fungi here described from material in the Herbarium at $\mathrm{Kew}$, five are Indian species collected by Mr. I. H. Burkill, Reporter on Economic Products to the Government of India ; two, from Christmas Island and from Borneo respectively, collected by Mr. H. N. Ridley, Director, Botanic Gardens, Singapore ; one from British Guiana, collected by Mr. A. W. Bartlett, Superintendent, Botanic Gardens, Georgetown; one from West Africa, collected by Mr. W. H. Johnson, formerly Director of Agriculture, Gold Coast; and one from New South Wales, collected by Mr. Cheel. 